\title{
Plasma thyroxine and triiodothyronine concentrations in growing and adult meat type birds fed "00" rapeseed-containing diet during the first seven weeks of life
}

\author{
Ewa Świerczewska ${ }^{1}$, Barbara Reklewska ${ }^{2}$ and Anna Siennicka ${ }^{1}$ \\ 'Department of Poultry Breeeding, Warsaw' Agricultural University \\ ${ }^{2}$ Institute for Cattle Breeding and Dairy Science, Warsaw Agricultural University, \\ Przejazd 4, 05-840 Bru'inów, Poland
}

(Received 5 December 1994; accepted 16 February 1995)

\begin{abstract}
In two series of experiments plasma thyroxine and triiodothyronine concentration were examined in 56 adult hens and 139 meat type chickens of Biala Brwinowska strain fed up to 7 weeks of age a diet containing "OO" rape seeds, wheat and barley (diet B) or maize, soyabean meal and wheat (diet C). Relationship between reproductive performance of adult hens and plasma thyroid hormone concentration was assessed.

At the age of 7 weeks, chickens fed diet B had significantly lower body weight (except of males in 1994) and, despite of its low (0.7-0.9 $\mu \mathrm{mol} / \mathrm{g})$ glucosinolate content, significantly higher plasma thyroxine concentration than control birds. No significant diet-related difference was found in their plasma $T_{3}$ level and $T_{3} / T_{4}$ ratio. Also no differences were found in reproductive perfomance of one year old hens related to the diet fed in the first 7 weeks of life. In addition, in both series of experiments plasma $T_{4}$ concentration was positively correlated with egg fertility $(P \leqslant 0.05)$ while $T_{3}$ negatively to the hatchability rate $(P \leqslant 0.01)$.
\end{abstract}

KEY WORDS: rapeseed meal, $T_{4}, T_{3}$, meat type chickens, adult hens, egg fertility, hatchability

\section{INTRODUCTION}

Numerous studies performed on broiler chickens provided well documented evidence that replacing in diet soyabean meal by rapeseed (even of low glucosinolate content) causes a significant increase in the weight of thyroid glands (Fritz et al.,1989; Rosiński and Swierczewska, 1990; Smulikowska at al.,1990). 
Simultaneously, feeding rapeseed meal may affect chicken growth rate and impair egg production and feed conversion in laying hens (Elwinger,1986). No information was found in a vailable literature concerning persistence of changes in thyroid gland activity (induced in period of intensive growth) and their posssible relation to reproductive performance of adult birds.

The purpose of the present study was to estimate plasma thyroid hormone levels in 7 week old, meat type chickens fed " 00 " rapeseed and then, in the same birds, in adult age at the end of the first hatching season in order to elucidate possible relationship between their plasma thyroxine and triiodothyronine levels and reproductive performance.

\section{MATERIAL AND METHODS}

\section{Animals and diets}

The study involved two consecutive generations of meat type chickens ( 92 in 1993 year and 47 in 1994) and one year old hens (26 in 1993 year and 30 in 1994) from a closed for 30 years population of Biała Brwinowska strain (Świerczewska et al.,1987).

TABLE ]

Composition of diets (\%) fed in the first 7 weeks of rearing in years 1993 and 1994

\begin{tabular}{lcccc}
\hline Ingredients & \multicolumn{2}{c}{$0-4$ weeks } & \multicolumn{2}{c}{$4-7$ weeks } \\
\cline { 2 - 5 } & C & B & C & B \\
\hline Maize & 52.0 & - & 54.2 & - \\
Wheat & 9.0 & 51.5 & 17.0 & 51.5 \\
Barley & - & 9.0 & - & 17.0 \\
Soyabean meal (42\% CP) & 27.4 & 22.0 & 19.2 & 13.1 \\
Rape seeds "00" & - & 6.0 & - & 7.5 \\
Meat meal (60\% CP) & 6.7 & 6.6 & 6.0 & 6.8 \\
Tallow & 2.8 & 2.9 & 1.6 & 2.1 \\
Sodium chloride & 0.2 & 0.2 & 0.2 & 0.2 \\
Dicalcium phosphate & 0.7 & 0.6 & 0.5 & 0.5 \\
L-Lysine (98\%) & 0.1 & 0.1 & 0.1 & 0.1 \\
DL-Methionine (99\%) & 0.1 & 0.1 & 0.2 & 0.2 \\
Mineral-vitamin premix & $1.0^{1}$ & $1.0^{\prime}$ & $1.0^{2}$ & $1.0^{2}$ \\
\hline Calculated: & & & & \\
Crude protein, \% & 21.59 & 21.52 & 19.53 & 19.56 \\
Metabolizable energy, MJ/kg & 12.69 & 12.64 & 12.69 & 12.69 \\
\hline
\end{tabular}

1- DKA Starter, ${ }^{2}$ - DKA Grower 
Chickens hatched in 1993 (males and females individually marked) were assigned to two alternative groups (B or C) and fed different diet. In the next year the offspring of hens fed the rapeseed-containing diet during the first 7 weeks of life were again assigned to group B.

A composition of the feed mixtures is given in Table 1. In the control diet (C) the main components were maize, wheat and soyabean meal. In the experimental diet (B) maize was replaced by wheat and barley and part of soyabean meal by OO-rape seeds ( $6.0 \%$ up to 4 weeks of age and $7.5 \%$ from 4 to 7 weeks of age). The glucosinolate content in " 00 " rape seeds amounted to $12 \mu \mathrm{mol} / \mathrm{g}$, so in diet B it ranged from 0.72 in starter to $0.90 \mu \mathrm{mol} / \mathrm{g}$ in finisher. Diets B and C were isoprotein ( $21 \% \mathrm{CP}$ during the initial period and $19 \%$ in the final period). The metabolizable energy level amounted to $12.7 \mathrm{MJ} / \mathrm{kg}$.

The chickens were fed diets B or C up to 7th week of life only. After which both groups were fed the same diets: up to week 20 a mixture containing $15 \%$ of protein, later a typical mixture for laying hens, containing $17 \%$ of protein and $11.5 \mathrm{MJ} \mathrm{ME} / \mathrm{kg}$ and no rapeseed.

\section{Growth and reproductive traits}

The body weight of the birds was recorded at 7 weeks of age. At the end of the hatching season, fertility and hatchability rate were recorded for two months in one-year-old hens to estimate their reproductive performance.

\section{Blood sampling and hormone assays}

Blood for estimation of plasma thyroid hormone concentration was taken in the morning to heparynized tubes by wing veni puncture, from seven week old chickens and one-year-old hens fasted overnight.

Within one hour following sampling, tubes were centrifuged with $3500 \mathrm{rpm}$ at $4^{\circ} \mathrm{C}$ and $300 \mu \mathrm{l}$ aliquots of plasma were stored at $-20^{\circ} \mathrm{C}$ until assayed. Plasma thyroxine $\left(\mathrm{T}_{4}\right)$ and triiodothyronine $\left(\mathrm{T}_{3}\right)$ concentrations were determined by RIA technique using commercial SPECTRIA kits produced by ORION, Diagnostica and distributed by POLATOM, Świerk (Poland).

The data were subjected to the analysis of variance; significance of differences between means for groups was checked using Duncan multiple range test. For evaluation of possible relationship between plasma hormone concentration and reproductive performance traits, coefficients of phenotypic correlation were calculated. 


\section{RESULTS AND DISCUSSION}

With the exception of the group of male chickens in 1993 which exhibited the highest variability, the diet significantly (1994) or highly significantly (1993) influenced the body weight of birds (Table 2).

In both years, the body weight of chickens fed the concentrate mixture containing " 00 " rape seeds and barley (no maize) during the first 7 weeks of life was lower (in males and females by 6.5 and $7.4 \%$, respectively) than that of chickens fed control diet. The results obtained in the present work confirm earlier investigations by Nwokolo and Sim (1989) comparing effects of similar feeds containing rape seeds, wheat and barley vs maize and soyabean meal on growth rate of broiler chickens.

TABLE 2

Body weight of control (C) and experimental (B) chicken at the age of 7 weeks, $g$

\begin{tabular}{|c|c|c|c|c|c|c|c|c|}
\hline \multirow[t]{2}{*}{ Year } & \multicolumn{4}{|c|}{ Males } & \multicolumn{4}{|c|}{ Females } \\
\hline & $\mathrm{n}$ & $x^{\mathrm{C}} \mathrm{SD}$ & n & $x^{B} S D$ & $n$ & $x^{c} S D$ & $\mathbf{n}$ & $x^{\prime \prime} S D$ \\
\hline 1993 & 22 & $1772^{\wedge} \pm 127$ & 24 & $1592^{\mathrm{B}} \pm 79$ & 22 & $1435^{\wedge} \pm 59$ & 24 & $1334^{\mathrm{B}} \pm 79$ \\
\hline 1994 & 13 & $1362^{\circ} \pm 130$ & 12 & $1290^{a} \pm 65$ & 12 & $1188^{\prime \prime} \pm 84$ & 11 & $1094^{h} \pm 100$ \\
\hline
\end{tabular}

means with different superscripts indicate significant differences between control $(C)$ and experimental (B) birds of the same sex within the same ycar: $a, b-P \leqslant 0.05 ; A, B-P \leqslant 0.01$

TABLE 3

Plasma thyroxine $\left(T_{4}\right)$ and triiodothyronine $\left(T_{3}\right)$ levels in 7 week old chickens, nmol/1

\begin{tabular}{|c|c|c|c|c|c|c|}
\hline \multirow[b]{2}{*}{ Year } & \multirow[b]{2}{*}{ Sex } & \multirow[b]{2}{*}{ Group } & \multirow[b]{2}{*}{$\mathbf{n}$} & $T_{4}$ & $T_{3}$ & \multirow[t]{2}{*}{$T_{3} / T_{4}$} \\
\hline & & & & SD & SD & \\
\hline \multirow{4}{*}{1993} & \multirow[t]{2}{*}{ Males } & $\mathrm{C}$ & 22 & $29.73^{a} \pm 12.09$ & $0.84^{2} \pm 0.46$ & 0.028 \\
\hline & & B & 24 & $33.33^{*} \pm 6.05$ & $0.92^{a} \pm 0.62$ & 0.028 \\
\hline & \multirow[t]{2}{*}{ Females } & $\mathrm{C}$ & 22 & $29.51 \times 7.26$ & $0.84^{a} \pm 0.69$ & 0.028 \\
\hline & & B & 24 & $34.36^{b} \pm 6.33$ & $0.79^{a} \pm 0.51$ & 0.023 \\
\hline \multirow{4}{*}{1994} & \multirow[t]{2}{*}{ Males } & $\mathrm{C}$ & 13 & $34.42^{\circ} \pm 8.33$ & $1.22^{\mathrm{a}} \pm 0.39$ & 0.035 \\
\hline & & B & 12 & $41.63^{b} \pm 8.93$ & $1.06^{4} \pm 0.43$ & 0.025 \\
\hline & \multirow[t]{2}{*}{ Females } & C & 12 & $32.00^{\wedge} \pm 8.08$ & $1.00^{*} \pm 0.41$ & 0.031 \\
\hline & & B & 11 & $45.33^{\mathrm{B}} \pm 10.18$ & $1.74^{a} \pm 1.49$ & 0.038 \\
\hline
\end{tabular}

means with different superscripts indicate significant differences between control $(C)$ and experimental (B) birds of the same sex within the same year: $a, b-P \leqslant 0.05 ; A, B-P \leqslant 0.01$ 
Data concerning plasma thyroid hormone concentration in growing chickens (Table 3) clearly indicate that chickens fed the rape seed-containing diet during the first 7 weeks of life, despite of its low glucosinolate content had, within exception of males in 1994, significantly higher plasma $\mathbf{T}_{4}$ level than control birds. Differences between groups in plasma $T_{3}$ levels were nonsignificant.

Comparison of the results obtained in this work with plasma thyroid hormone levels estimated in broiler chickens of about the same age indicate that while the plasma $T_{4}$ concentration considerably exceeded tha range of values described by Leenstra et al. (1991), plasma $T_{3}$ levels of all birds, particularly those fed " 00 " rape seeds, were below those found by the above mentioned authors, as well as by Stewart et al.(1983). Due to the above described differences in plasma concentrations of thyroid hormones, the $T_{3} / T_{4}$ ratio found in this study was considerably lower from values presented by Leenstra et al. (1991). However, no significant effect of feeding regime was noted in regards to the $T_{3} / T_{4}$ ratio in male and female chickens of both experimental series.

The higher plasma $T_{4}$ concentration in chickens fed the rape seed-containing diet may be a result of compensatively enlarged thyroid gland. Similar effect were described by Koreleski et al.(1986) and Uzięblo et al.(1987), who examined the influence of " 00 " rapeseed meal supplement on thyroid gland morphology of broiler chickens and adult hens.

However, $\mathrm{T}_{4}$ is only a prohormone, and according to Scanes and Harvey (1989), is less effective than $T_{3}$ in the inhibition of growth hormone release. Probably therefore, high plasma $\mathrm{T}_{4}$ levels resulted only in $6.5-7.4 \%$ decrease of body weight. Low $T_{3}$ plasma levels coinciding with a high concentration of $T_{4}$ suggest a decreased deiodination rate. Thus, such a situation reflects relatively low thyroid activity.

The great variability of the results occurring due to the moulting effect in 1993 (increased thyroid hormone concentration), and resulting from exceptional heat-waves in the summer of 1994 (decreased hormone levels), were the reasons why the differences in plasma thyroid hormone concentrations between hens fed different diets during the first 7 weeks of life were statistically insignificant (Table 4).

In both experimental series, increased plasma $T_{4}$ concentration positively correlated with egg fertility rate (Table 5). Correlation coefficients in succesive years were 0.226 and 0.406 , respectively $(P \leqslant 0.05)$. On the other hand, $T_{3}$ negatively affected the hatchability rate. The correlation coefficients $(r=-0.458$ and -0.558$)$ were highly significant $(P \leqslant 0.01)$ in both years.

The results presented here are in contrast with those previously reported by Christensen and Ort (1990), who demonstrated increased hatchability of turkey eggs injected with $\mathbf{T}_{3}$. Christensen et al. (1991), in a later publication, demonstrated a positive, significant effect of thyroid hormones on hatchability. 
TABLE 4

Plasma thyroxine and triiodothyronine concentration of adult hens fed "00" rape seeds during the first 7 weeks of life, nmol/1

\begin{tabular}{|c|c|c|c|c|c|}
\hline \multirow[t]{2}{*}{ Year } & \multirow[t]{2}{*}{ Group } & \multirow[b]{2}{*}{$\mathrm{n}$} & $\mathbf{T}_{4}$ & $\mathrm{~T}_{3}$ & \multirow[t]{2}{*}{$\mathrm{T}_{3} / \mathrm{T}_{4}$} \\
\hline & & & SD & $\mathrm{SD}$ & \\
\hline \multirow[t]{2}{*}{1993} & C & 16 & $41.87^{a} \pm 6.89$ & $4.14^{\mathrm{a}} \pm 6.03$ & 0.099 \\
\hline & B & 10 & $45.05^{\circ} \pm 4.00$ & $5.72^{a} \pm 6.03$ & 0.127 \\
\hline \multirow[t]{2}{*}{1994} & $\mathrm{C}$ & 13 & $36.39^{\mathrm{a}} \pm 5.08$ & $0.99^{a} \pm 0.17$ & 0.027 \\
\hline & B & 17 & $37.82^{\circ} \pm 6.14$ & $0.99^{\circ \mathrm{i}} \pm 0.26$ & 0.026 \\
\hline
\end{tabular}

means with the same superscripts indicate no significant differences between control $(C)$ and experimental (B) birds within the same year

TABLE 5

Fertility and hatchability (\%) and coefficients of phenotypic correlation (rp) between plasma thyroid hormones level and egg fertility and hatchability rate

\begin{tabular}{lcc}
\hline & \multicolumn{2}{c}{ Y e a T } \\
\cline { 2 - 3 } Variable & 1993 & 1994 \\
\hline & & 91.9 \\
Fertility, \% & 91.6 & 90.0 \\
Hatchability, \% & 92.7 & $0.406^{*}$ \\
$\mathrm{~T}_{4}$ - fertility, rp & $0.226^{*}$ & $-0.060^{*}$ \\
$\mathrm{~T}_{3}$ - fertility, rp & -0.084 & $-0.223^{* *}$ \\
$\mathrm{~T}_{4}$ - hatchability, rp & -0.109 & $-0.558^{* *}$ \\
$\mathrm{~T}_{3}$ - hatchability, rp & $-0.458^{* *}$ & \\
\hline
\end{tabular}

statistically significant at:

$*-\mathrm{P} \leqslant 0.05$

$* *-P \leqslant 0.01$

However, it should be emphasized that mentioned authors supplemented hypothyroid subjects with $T_{3}$. It seems important that the plasma $T_{4}$ concentration described by Christensen at al. (1991) in control broiler chickens was about 4 times lower than respective values found in this study. It should be assumed that the relationship between plasma thyroid hormone concentration and reproductive performance depends on the current thyroid status of birds.

\section{CONCLUSIONS}

The significant rise of plasma $T_{4}$ level, coinciding with low plasma $T_{3}$ concentration in chickens fed a diet containing low glucosinolate rape seeds, is suggestive of a diet-suppressed $\mathrm{T}_{4}$ deiodination rate. 
A diet containing $7.5 \%$ of rape seeds and barley plus wheat as substitutes of maize resulted in a $7 \%$ decrease of chicken body weight at the age of 7 weeks.

Feeding " 00 " rape seeds diet during the early growth period did not affect reproductive performance of one-year-old hens.

The plasma $T_{4}$ concentration determined at the end of reproductive season seems to be positively correlated $(P \leqslant 0.05)$ with egg fertility, while the plasma $T_{3}$ level negatively correlated $(\mathrm{P} \leqslant 0.01)$ with hatchability rate.

\section{REFERENCES}

Christensen V.L., Ort J.F., 1990. Influence of diet mediated maternal thyroid alterations on functional properties of turkeys cggs. Poultry Sci. 69, 1576-1581

Christensen V.L., Donaldson W.F.. Ortland J.F.. Grimes J.L., 1991. Influence of diet mediated maternal thyroid alterations on hatchability and metabolism of turkey cmbryos. Poultry Sci. 70, 1594-1601

Tiwinger K., 1986. Continued experiments with rapeseed meal of a Swedish low glucosinolate type fed to poultry. Swedish J. Agric. Res. 16, 35-41

Fritz Z., Schleicher A., Kinal $\Lambda$., Jarosz L., Jamro\% D., 1989. Feed mixiures with rapesed and extracted rapeseed meal of Jantar variety in feeding of broiler chickens (in Polish). Zesz. Nauk drob. VI, 55-67

Koreleski J., Ryś R., Młodkowski M., Ombach A., Kubič M., 1986. Effect of feeding of olimeal from traditional or low-glucosinolate rapeseeds on performance and vitanin - mincral supply of broiler chickens and growth of rats (in Polish). Rocz. Nauk. Zoot., Monogr. Rurpr. 24, 282-297

Leenstra R., Decupere [.., Beuving G., Buyse J., Berghman L., Herremans M., 1991. Concentrations of hormones, glucose, triglycerides and free fatty acids in the plasma of broiler chickens selected for weight gain and food conversion. Brit. Poultry Sci. 32, 619-632

Nwkolo E., Sim J., 1989. Barley and full-fat Canola seed in broiler diets. Poultry Sci. 68, 1374-1380

Rosiński T., Świercyewska F., 1990. Rapeseed meal as a component of a diet for broiler (in Polish). Zesz. Nauk. drob. VII, 23-29

Scanes C.G., Harvey S., 1989. Triiodothyronine inhibition of thyrotropin-releasing hormone and growth hormone-releasing factor induced growth hormone sccrction in anesthetized chickens. Gen. Comp. Endocrinol. 73, 477-484

Smulik owska S.. Chibowska M.. Wiśnicwska J., 1990. Effects of low glucosinolate rape-seed raw, pressed or extracted on performance, thyroid status and fatty acid profile of broiler chicken. Proceedings of VIII Furopean Poultry Conference, Barcelona, 348-351

Stewart P.A., Washburn K.W., 1983. Variation in growth hormone, triiodothyronine $\left(\mathrm{T}_{3}\right)$ and lipogenic enzyme activity in broiler strains differing in growth and fatness. Growth 47, 411-425

Swierczewska E., Grzybowska A., Siennicka A., 1987. Results of selection conducled in a flock of meat type chicken (in Polish). Prace Mat. Zoot. 38, 51-57

Uziębło W.. Zięba J.. Witkowski A., Brodacki A., 1987. Body weight and some morphological and histological features in hens fed diets containing rapeseed meal and in their progeny (in Polish). Zesz. Nauk. drob. IV, 63-72 


\section{STRESZCZENIE}

Poziom $T_{4} i T_{3}$ w osoczu kurcząt i dorosłych kur typu mięsnego żywionych mieszanką zawierającą rzepak $00 \mathrm{w}$ ciągu pierwszych 7 tygodni zycia

W dwóch seriach doświadczeń, przeprowadzonych w latach 1993 i 1994, oznaczano poziom hormonów tarczycy u (lącznie) 139 kurcząt i 56 dorosłych kur typu mięsnego, rodu Biake Brwinowskic, żywionych do wieku 7 tygodni micszanką zawicrającą rzepak " 00 ", pszenicę i jęczmien (grupa B) lub mieszankę zawierającą kukurydzę, pszenicę i śrutę sojową (grupa C). Oceniano zależność między cechami użytkowości rozpłodowej i stężeniem $T_{4} \mathrm{i} \mathrm{T}_{3}$ w osoczu kur. W obydwóch latach (z wyjątkiem kogutów z roku 1994) stwierdzono istotnie mniejszą masę ciała kurcząt 7 tygodniowych $w$ grupic $B$. Kurczęta $z$ tej grupy miały istotnie wyższy poziom $T_{4}$ (z wyjątkiem kogutów z roku 1993) w porównaniu z kurczętami z grupy C. Nie stwicrdzono istolnych różnic w stçżeniu $\mathrm{T}_{3} \mathrm{i}$ w stosunku $\mathrm{T}_{3} \mathrm{~T}_{4}$ międ y grupami żywionymi różnymi mieszankami. Skład mieszanki skarmiancj do wicku 7 tygodni nie miał następczego wpływu na wyniki zapłodnienia i wylęgu jaj. W obydwóch doświadczeniach poziom $\mathrm{T}_{4}$ w osoczu był dodatnio skorelowany $z$ wskaźnikiem zapłodnienia jaj $(P \leqslant 0,05)$, a poziom $T_{3}$ ujemnie ze wskaźnikiem wylęgowości $(P \leqslant 0,01)$. 